\title{
Two Novel Sesquiterpenes and A New Pregnane Derivative from the South China Sea Gorgonian Subergorgia suberosa Xian-Qiang Chen ${ }^{1,2}$, Nannan Xing $\oplus^{3}$, Bin Yang $\oplus^{2}$, Xuefeng Zhou $\odot^{2}$,
Chenghai Gao ${ }^{1}$ and Yonghong Liu ${ }^{1,2}$ *
}

${ }^{1}$ Institute of Marine Drugs, Guangxi University of Chinese Medicine, Nanning, Guangxi 530200, P. R. China

${ }^{2}$ Key Laboratory of Marine Bio-resources Sustainable Utilization; Guangdong Key Laboratory of Marine Materia Medica; Research Center for Marine Microbes, South China Sea Institute of Oceanology, Chinese Academy of Sciences, Guangzhou, Guangdong 510301, P. R. China

${ }^{3}$ Guangxi Key Laboratory of Chinese Medicine Foundation Research, Guangxi Scientific Experimental Center of Traditional Chinese Medicine, Guangxi University of Chinese Medicine, Nanning, Guangxi 530200, P. R. China

(Received April 22, 2019; Revised May 25, 2019; Accepted May 26, 2019)

\begin{abstract}
Two novel sequiterpenes isosuberosenol A (1), suberosain A (2), and a new pregnane derivative 4hydroxymethyl-5 $\beta$-pregnan-3, 20-dione (3) have been isolated from the South China Sea gorgonian Subergorgia suberosa. Their structure and relative stereochemistry were established based on the detailed spectroscopic analysis, including HR-ESI-MS, 1D- and 2D NMR spectra. The skeleton of isosuberosenol A (1) have been previously undescribed. The discovery of isosuberosenol A (1) provides some strong support for the plausible biogenetic pathway of quadrone type sesquiterpenes.
\end{abstract}

Keywords: Sesquiterpene; pregnane derivative; Subergorgia suberosa. (C) 2019 ACG Publications. All rights reserved.

\section{Introduction}

The previous studies have been reported that several novel sequiterpenes [1-6], pregnane derivatives [7, 8], secosteroids [9-11], and alkaloids [12] were isolated from Subergorgia suberosa. Some of these natural products exhibited a variety of biological activities such as cytotoxicity [2, 4, 5, 13, 14], antibacterial [15], antifungal [15], antifouling [16, 17], and anti-flu virus effects [8]. In a search for novel active compounds from gorgonians, we investigated the South China Sea gorgonian $S$. suberosa. Two novel sesquiterpenes isosuberosenol A (1), suberosain A (2), and a new pregnane derivative 4-hydroxymethyl-5 $\beta$-pregnan-3, 20dione (3) were isolated from a red gorgonian $S$. suberosa. Herein we describe the isolation and structure elucidation of 1-3.

\footnotetext{
* Corresponding author: E-Mail: yonghongliu@ @scsio.ac.cn ; Phone: +86-020-8902-3244 Fax: +86-020-8902-3244
} 


\section{Materials and Methods}

\subsection{General}

NMR spectra were recorded on a Bruker AV-500 MHz spectrometer with TMS as the internal standard. HR-ESI-MS data were obtained on an LTQ Orbitrap XL ${ }^{\text {TM }}$ Hybrid Ion Trap-Orbitrap FT-MS spectrometer. TLC was carried out on silica gel $\mathrm{GF}_{254}$ plates (Yantai Institute of Chemical Industry, Yantai, China) and spots were visualized by UV light (254 and / or $365 \mathrm{~nm}$ ) and spraying with $10 \% \mathrm{H}_{2} \mathrm{SO}_{4}$ ethanol solution followed by heating. Column chromatography was carried out using silica gel (Qingdao Haiyang Chemical Co., Ltd., Qingdao, China), ODS (35-70 $\mu \mathrm{m}$, Grace, Maryland, USA), MCI gel (75-150 $\mu \mathrm{m}$, Mitsubishi Chemical Corporation, Tokyo, Japan), and Sephadex LH-20 (GE Healthcare Bio-Science AB, Uppsala, Sweden) as packing materials.

\subsection{Animal Material}

Subergorgia suberosa were collected from Sanya Bay, Hainan province, P. R. China in April 2010. The animal material was identified as Subergorgia suberosa (Pallas) by Professor Hui Huang who works in South China Sea Institute of Oceanology, Chinese Academy of Sciences. A voucher specimen (No. LSH-201003) has been deposited in the Key Laboratory of Marine Bio-resources Sustainable Utilization, South China Sea Institute of Oceanology, Chinese Academy of Sciences, Guangzhou, China.

\subsection{Extraction and Isolation}

The $S$. suberosa. (5.5 Kg, wet weight) was soaked in EtOH immediately after collection. The specimen was extracted with $95 \% \mathrm{EtOH}$ three times at room temperature, and the solution was evaporated in vacuum to obtain the crude extracts. The crude extracts were suspended in $\mathrm{H}_{2} \mathrm{O}$ and extracted with $\mathrm{CHCl}_{3}$ three times. The $\mathrm{CHCl}_{3}$ extract was concentrated to afford $70.2 \mathrm{~g}$ residue. It was subjected to medium pressure column chromatography using silica gel $(40-60 \mu \mathrm{m})$ as packing material, and eluted with a gradient system of petroleum ether-EtOAc (100:0-0:100, v/v) to yield six fractions (F1-F6). F2 was successively separated by ODS column chromatography $\left(\mathrm{MeOH}-\mathrm{H}_{2} \mathrm{O}, 20: 80-100: 0\right.$, v/v), sephadex LH-20 column chromatography $(\mathrm{MeOH})$, and silica gel column chromatography $\left(\mathrm{CHCl}_{3}-\mathrm{MeOH}, 100: 0-20: 80\right.$, v/v) to obtain $2(5.1 \mathrm{mg})$. F3 was subjected to silica gel column chromatography eluted with petroleum ether-Me ${ }_{2} \mathrm{CO}(100: 0-0: 100, \mathrm{v} / \mathrm{v})$, followed by sephadex LH-20 column chromatography $\left(\mathrm{CHCl}_{3}-\mathrm{MeOH}, 50: 50\right.$, v/v) and preparative thin layer chromatography (petroleum ether- $\left.\mathrm{Me}_{2} \mathrm{CO}, 80: 20, \mathrm{v} / \mathrm{v}\right)$ to afford $\mathbf{1}(4.0 \mathrm{mg})$. F4 was subjected to silica gel column chromatography using $\mathrm{CHCl}_{3}-\mathrm{Me}_{2} \mathrm{CO}(20: 1-0: 1$, v/v) as eluent to give eight fractions (F41-F48). F42 was fractionated by ODS column chromatography eluted with $\mathrm{MeOH}-\mathrm{H}_{2} \mathrm{O}(20: 80-100: 0$, v/v), and then subjected to silica gel column chromatography eluted with a gradient system of $\mathrm{CHCl}_{3}-\mathrm{MeOH}$ (90:10-10:90, $\mathrm{v} / \mathrm{v})$ to yield $\mathbf{3}(3.2 \mathrm{mg})$.

Isosuberosenol A (1): Colorless crystal; ${ }^{1} \mathrm{H}$ NMR $\left(500 \mathrm{MHz}, \mathrm{CDCl}_{3}\right)$ and ${ }^{13} \mathrm{C}$ NMR $\left(125 \mathrm{MHz}, \mathrm{CDCl}_{3}\right)$ spectral data see Table 1; HR-ESI-MS at $m / z 261.1813[\mathrm{M}+\mathrm{Na}]^{+}$(calcd. for $\mathrm{C}_{15} \mathrm{H}_{26} \mathrm{O}_{2} \mathrm{Na}, 261.1831$ ).

Suberosain A (2): White oil; ${ }^{1} \mathrm{H}$ NMR (500 MHz, $\left.\mathrm{CDCl}_{3}\right)$ and $\left.{ }^{13} \mathrm{C} \mathrm{NMR} \mathrm{(125} \mathrm{MHz,} \mathrm{CDCl}_{3}\right)$ spectral data see Table 1; HR-ESI-MS at $m / z 261.1814[\mathrm{M}-\mathrm{H}]^{+}$(calcd. for $\mathrm{C}_{17} \mathrm{H}_{25} \mathrm{O}_{2}, 261.1855$ ).

4-Hydroxymethyl-5 $\beta$-pregnan-3, 20-dione (3): White powder; ${ }^{1} \mathrm{H} \mathrm{NMR}\left(500 \mathrm{MHz}, \mathrm{CDCl}_{3}\right)$ and ${ }^{13} \mathrm{C} \mathrm{NMR}$ $\left(125 \mathrm{MHz}, \mathrm{CDCl}_{3}\right.$ ) spectral data see Table 2; HR-ESI-MS at $m / z 369.2393[\mathrm{M}+\mathrm{Na}]^{+}$(calcd. for $\mathrm{C}_{22} \mathrm{H}_{34} \mathrm{O}_{3} \mathrm{Na}$, 369.2406). 


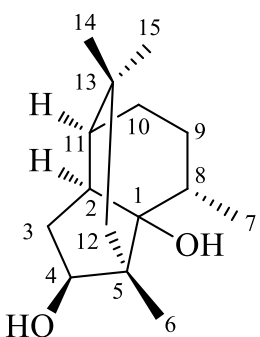

1

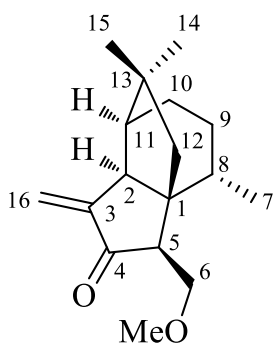

2

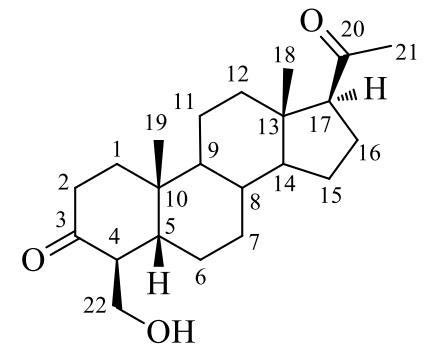

3

Figure 1. Chemical structure of compounds 1-3

\section{Results and Discussion}

Compound 1 was obtained as a colorless crystal. Its molecular formula was determined to be $\mathrm{C}_{15} \mathrm{H}_{26} \mathrm{O}_{2}$ based on the NMR spectra and HR-ESI-MS ion peak at $m / z 261.1813[\mathrm{M}+\mathrm{Na}]^{+}$(calcd. for $\mathrm{C}_{15} \mathrm{H}_{26} \mathrm{O}_{2} \mathrm{Na}$, 261.1831), indicating 3 degrees of unsaturation. The ${ }^{1} \mathrm{H}$ NMR spectrum displayed the presence of four methyl groups $\left[\delta_{\mathrm{H}} 0.90(3 \mathrm{H}, \mathrm{s}), \delta_{\mathrm{H}} 1.13(3 \mathrm{H}, \mathrm{s}), \delta_{\mathrm{H}} 1.14(3 \mathrm{H}, \mathrm{d}, J=7.0 \mathrm{~Hz})\right.$, and $\left.\delta_{\mathrm{H}} 1.00(3 \mathrm{H}, \mathrm{s})\right]$. The ${ }^{13} \mathrm{C} \mathrm{NMR}$ and DEPT spectra showed the presence of four methyls $\left(\delta_{\mathrm{C}} 15.8,18.1,31.0\right.$, and 34.3$)$, four methylenes $\left(\delta_{\mathrm{C}} 38.9\right.$, $29.4,24.9$, and 51.3$)$, four methines $\left(\delta_{\mathrm{C}} 45.8,80.5,30.8\right.$, and 46.0$)$, and three quaternary carbons $\left(\delta_{\mathrm{C}} 83.4\right.$, 50.1, and 31.7). The above NMR and MS data suggested that 1 was similar to suberosenol A [14]. The differences were the presence of a methyl at C3 in 1 instead of an olefin in suberosenol A, and an additional hydroxyl group in $\mathbf{1}$.

The gross structure of 1 was determined by the 2D NMR experiments, including ${ }^{1} \mathrm{H}-{ }^{1} \mathrm{H}$ COSY and HMBC (Figure 2). The methyl attached to C-5 was confirmed based on the analysis of the HMBC cross peaks of $\delta_{\mathrm{H}} 1.00\left(\mathrm{H}_{3}-6\right)$ with $\delta_{\mathrm{C}} 80.5(\mathrm{C}-4), 50.1(\mathrm{C}-5), 83.4(\mathrm{C}-1)$, and $51.3(\mathrm{C}-12)$. The key HMBC correlations of $\delta_{\mathrm{H}} 2.19(\mathrm{H}-2), 2.50(\mathrm{H}-3 \mathrm{a}), 3.96(\mathrm{H}-4), 1.00\left(\mathrm{H}_{3}-6\right), 1.14\left(\mathrm{H}_{3}-7\right)$, and $2.09(\mathrm{H}-8)$ with $\delta_{\mathrm{C}} 83.4$ (C-1), together with molecular formula $\mathrm{C}_{15} \mathrm{H}_{26} \mathrm{O}_{2}$, suggested that a hydroxyl group was attached to the position of $\mathrm{C} 1$. The key HMBC correlations of $\delta_{\mathrm{H}} 1.70(\mathrm{H}-12 \mathrm{a})$ and $1.41(\mathrm{H}-12 \mathrm{~b})$ with $\delta_{\mathrm{C}} 50.10(\mathrm{C}-5), 15.8$ (C-6), and 80.5 (C-4) revealed that the methylene at C12 was linked to C5. The planar structure of 1 was unambiguously established on the basis of analysis ${ }^{1} \mathrm{H}-{ }^{1} \mathrm{H}$ COSY and $\mathrm{HMBC}$ spectra.

The relative stereochemistry of $\mathbf{1}$ was confirmed by NOESY experiment (Figure 3). The key NOESY correlations of $\delta_{\mathrm{H}} 2.19(\mathrm{H}-2)$ with $\delta_{\mathrm{H}} 1.14\left(\mathrm{H}_{3}-7\right)$ and $1.60(\mathrm{H}-11)$ indicated that $\mathrm{H}-2, \mathrm{H}_{3}-7$, and $\mathrm{H}-11$ were situated in the same side of the six membered ring and assigned as the $\alpha$-orientation. The key NOESY correlations of $\delta_{\mathrm{H}} 1.14\left(\mathrm{H}_{3}-7\right)$ with $\delta_{\mathrm{H}} 3.96(\mathrm{H}-4)$ suggested that $4-\mathrm{OH}$ was $\beta$-oriented. The methyl at C6 was $\beta$-oriented on the basis of the key NOESY correlations of $\delta_{\mathrm{H}} 1.00\left(\mathrm{H}_{3}-6\right)$ with $\delta_{\mathrm{H}} 2.09(\mathrm{H}-8)$. Therefore, the structure of 1 was elucidated as $(1 R, 2 S, 3 \mathrm{a} S, 4 S, 7 S)$-1, 7, 8, 8-tetramethyloctahydro-1H-1, 4-ethanoindene2, 7a-diol (isosuberosenol A).

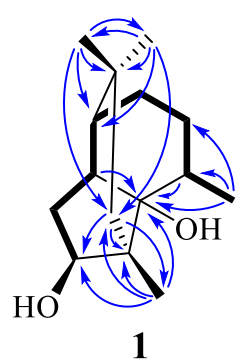

1

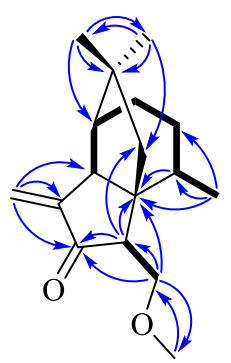

2

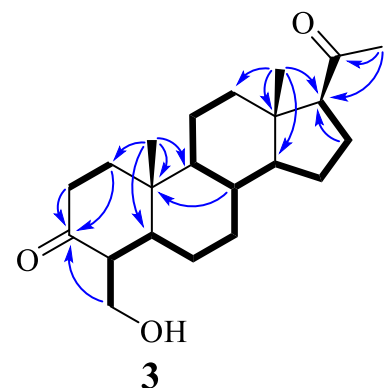

3

$$
-{ }^{1} \mathrm{H}-{ }^{1} \mathrm{H} \text { COSY }(\mathrm{H} \leftrightarrow \mathrm{H}) \quad \sim \mathrm{HMBC}(\mathrm{H} \rightarrow \mathrm{C})
$$

Figure 2. The key HMBC and ${ }^{1} \mathrm{H}-{ }^{1} \mathrm{H}$ COSY correlations of $\mathbf{1}-\mathbf{3}$ 


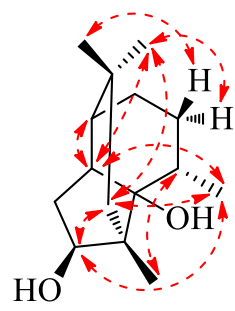

1

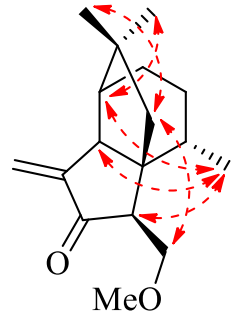

2

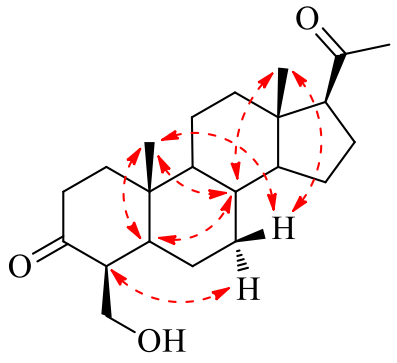

3

\section{$\sim \operatorname{NOESY}(\mathrm{H} \leftrightarrow \mathrm{H})$}

Figure 3. The key NOESY correlations of $\mathbf{1}-\mathbf{3}$

Table 1. ${ }^{1} \mathrm{H}(500 \mathrm{MHz})$ and ${ }^{13} \mathrm{C}(125 \mathrm{MHz})$ NMR Spectroscopic Data in $\mathrm{CDCl}_{3}$ for $\mathbf{1}$ and $\mathbf{2}\left(\delta_{\mathrm{H}}\right.$ and $\delta_{\mathrm{C}}$ in ppm, $J$ in $\mathrm{Hz}$ )

\begin{tabular}{|c|c|c|c|c|c|c|}
\hline \multirow[b]{2}{*}{ No. } & \multicolumn{3}{|c|}{1} & \multicolumn{3}{|c|}{2} \\
\hline & $\delta_{\mathbf{H}}$ & $\delta_{\mathrm{C}}$ & HMBC & $\delta_{\mathrm{H}}$ & $\delta \mathrm{C}$ & HMBC \\
\hline 1 & & 83.4 & $\begin{array}{l}\text { H-4, H-3a, H-2, H- } \\
8, \text { H-7, H-6, H-12b }\end{array}$ & & 54.2 & $\begin{array}{c}\text { H-5, H-6a, H-6b, H- } \\
\text { 7, H-8, H-9a, H-11, } \\
\text { H-12a, H-12b }\end{array}$ \\
\hline 2 & $2.19 \mathrm{dd}(7.5,3.0)$ & 45.8 & $\begin{array}{c}\text { H-3a, H-3b, H-8, } \\
\text { H-10a, H-10b }\end{array}$ & $2.81 \mathrm{brs}$ & 50.1 & $\begin{array}{c}\text { H-16a, H-16b, H- } \\
12 a, H-12 b\end{array}$ \\
\hline 3 & $\begin{array}{c}2.50 \mathrm{dd}(15.0,7.5, \mathrm{H}- \\
3 \mathrm{a}) ; 1.83 \mathrm{ddd}(15.0 \\
\quad 7.5,3.0, \mathrm{H}-3 \mathrm{~b})\end{array}$ & 38.9 & & & 148.8 & H-16a \\
\hline 4 & $3.96 \mathrm{~m}$ & 80.5 & $\begin{array}{c}\mathrm{H}-3 \mathrm{~b}, \mathrm{H}-2, \mathrm{H}-12 \mathrm{a}, \\
\mathrm{H}-12 \mathrm{~b}, \mathrm{H}-6\end{array}$ & & 207.3 & $\begin{array}{c}\text { H-16a, H-16b, H-6a, } \\
\text { H-6b, H-5 }\end{array}$ \\
\hline 5 & & 50.10 & $\begin{array}{c}\text { H-3a, H-2, H-8, H- } \\
\text { 12a, H-12b, H-6 }\end{array}$ & $2.71 \mathrm{dd}(7.0,4.5)$ & 54.5 & $\begin{array}{c}\text { H-6a, H-6b, H-8, H- } \\
12 a, H-12 b\end{array}$ \\
\hline 6 & $1.00 \mathrm{~s}$ & 15.8 & $\mathrm{H}-12 \mathrm{a}, \mathrm{H}-12 \mathrm{~b}$ & $\begin{array}{c}3.80 \mathrm{dd}(10.0,4.5, \\
\mathrm{H}-6 \mathrm{a}) ; 3.39 \mathrm{dd} \\
(10.0,7.5, \mathrm{H}-6 \mathrm{~b})\end{array}$ & 70.8 & $\mathrm{H}-5, \mathrm{H}-\mathrm{OMe}$ \\
\hline 7 & $1.14 \mathrm{~d}(7.0)$ & 18.1 & H-8, H-9a & $1.05 \mathrm{~d}(7.0)$ & 16.7 & H-8 \\
\hline 8 & $2.09 \mathrm{~m}$ & 30.8 & H-9a, H-7 & $2.08 \mathrm{~m}$ & 36.0 & $\mathrm{H}-12 \mathrm{a}, \mathrm{H}-12 \mathrm{~b}, \mathrm{H}-7$ \\
\hline 9 & $\begin{array}{c}1.90 \mathrm{~m}, \mathrm{H}-9 \mathrm{a} ; 1.38 \mathrm{~m}, \\
\mathrm{H}-9 \mathrm{~b}\end{array}$ & 29.4 & $\mathrm{H}-8, \mathrm{H}-7$ & $\begin{array}{c}2.06 \mathrm{~m}, \mathrm{H}-9 \mathrm{a} ; 1.32 \\
\text { ddd }(12.5,6.5,1.5 \text {, } \\
\text { H-9b) }\end{array}$ & 27.0 & H-8, H-7, H-11 \\
\hline 10 & $\begin{array}{c}1.63 \mathrm{~m}, \mathrm{H}-10 \mathrm{a} ; 1.51 \\
\mathrm{~m}, \mathrm{H}-10 \mathrm{~b}\end{array}$ & 24.9 & H-8, H-9a, & $1.67 \mathrm{~m}$ & 27.1 & H-9a, H-8, H-11 \\
\hline 11 & $1.60 \mathrm{~m}$ & 46.0 & $\begin{array}{l}\text { H-2, H-3a, H-3b, } \\
\text { H-9b, H-10a, H- } \\
\text { 10b, H-14, H-15 }\end{array}$ & $2.05 \mathrm{~m}$ & 50.3 & $\mathrm{H}-14, \mathrm{H}-15, \mathrm{H}-12 \mathrm{a}$, \\
\hline 12 & $\begin{array}{l}1.71 \mathrm{~d}(15.0, \mathrm{H}-12 \mathrm{a}) \\
1.40 \quad(15.0, \mathrm{H}-12 \mathrm{~b})\end{array}$ & 51.3 & H-6, H-14, H-15 & $\begin{array}{c}1.52 \mathrm{~d}(14.0, \mathrm{H}- \\
12 \mathrm{a}) ; 1.35 \mathrm{~d}(14.0, \\
\mathrm{H}-12 \mathrm{~b})\end{array}$ & 47.8 & H-5, H-14, H-15 \\
\hline 13 & & 31.7 & $\begin{array}{l}\text { H-2, H-12a, H- } \\
12 \mathrm{~b}, \mathrm{H}-14, \mathrm{H}-15\end{array}$ & & 40.0 & $\begin{array}{c}\mathrm{H}-12 \mathrm{a}, \mathrm{H}-12 \mathrm{~b}, \mathrm{H}-14, \\
\mathrm{H}-15\end{array}$ \\
\hline 14 & $0.90 \mathrm{~s}$ & 31.0 & H-12a, H-15 & $1.11 \mathrm{~s}$ & 26.1 & $\mathrm{H}-12 \mathrm{a}, \mathrm{H}-12 \mathrm{~b}, \mathrm{H}-15$ \\
\hline 15 & $1.13 \mathrm{~s}$ & 34.3 & $\begin{array}{c}\mathrm{H}-12 \mathrm{a}, \mathrm{H}-12 \mathrm{~b}, \mathrm{H}- \\
14\end{array}$ & $0.97 \mathrm{~s}$ & 34.4 & H-12a, H-12b, H-14 \\
\hline 16 & & & & $\begin{array}{c}6.09 \text { dd }(3.5,1.0, \\
\text { H-16a); } 5.32 \mathrm{dd} \\
(3.5,1.0, \mathrm{H}-16 \mathrm{~b})\end{array}$ & 119.0 & \\
\hline 6-OMe & & & & $3.32 \mathrm{~s}$ & 59.1 & H-6a, H-6b \\
\hline
\end{tabular}


Compound 2 was isolated as a colorless oil. Its molecular formula was established as $\mathrm{C}_{17} \mathrm{H}_{26} \mathrm{O}_{2}$ with 5 degrees of unsaturation on the basis of the HR-ESI-MS ion peak at $m / z 243.1749[\mathrm{M}-2 \mathrm{H}-\mathrm{OH}]^{+}(\mathrm{calcd}$. for $\left.\mathrm{C}_{17} \mathrm{H}_{23} \mathrm{O}, 243.1749\right)$ and NMR spectra. The ${ }^{1} \mathrm{H}$ NMR spectrum showed the presences of two methyl singlets $\left[\delta_{\mathrm{H}} 1.11(3 \mathrm{H}, \mathrm{s})\right.$ and $\left.0.97(3 \mathrm{H}, \mathrm{s})\right]$, a methyl doublet at $\delta_{\mathrm{H}} 1.05(3 \mathrm{H}, \mathrm{d}, J=7.0 \mathrm{~Hz})$, a methoxyl group at $\delta_{\mathrm{H}}$ $3.32(3 \mathrm{H}, \mathrm{s})$, and two olefin protons $\left[\delta_{\mathrm{H}} 6.09(1 \mathrm{H}, \mathrm{dd}, J=3.5,1.0 \mathrm{~Hz})\right.$ and $\left.5.32(1 \mathrm{H}, \mathrm{dd}, J=3.5,1.0 \mathrm{~Hz})\right]$. The ${ }^{13} \mathrm{C}$ NMR spectrum, combined with the DEPT and HSQC spectra, displayed the presence of 17 carbons, including four methyl groups $\left(\delta_{\mathrm{C}} 16.7,26.1,34.4\right.$, and 59.1), five methylenes $\left(\delta_{\mathrm{C}} 27.0,27.1,47.8,70.8\right.$, and $119.0)$, four methines $\left(\delta_{\mathrm{C}} 36.0,50.1,50.3\right.$, and 54.5), and four quaternary carbons including one carbonyl group and one olefin carbon. The spectroscopic data indicated that the structure of $\mathbf{2}$ was highly similar to that of suberosanone [14]; however, 2 showed the presence of an additional exocyclic olefin, a methoxyl group, and an oxygenated methylene instead of methyl in suberosanone. The NMR singals $\left[\delta_{\mathrm{C}} 148.8(\mathrm{C})\right.$ and $\left.119.0\left(\mathrm{CH}_{2}\right), \delta_{\mathrm{H}} 6.10(1 \mathrm{H}, \mathrm{dd}, J=3.5,1.0 \mathrm{~Hz}), 5.32(1 \mathrm{H}, \mathrm{dd}, J=3.5,1.0 \mathrm{~Hz})\right]$, together with HR-ESI-MS spectrum, suggested the presence of one exocyclic olefin. The hypothesis was confirmed by the key $\mathrm{HMBC}$ correlations from $\delta_{\mathrm{H}} 6.10(\mathrm{H}-16 \mathrm{a})$ and $5.32(\mathrm{H}-16 \mathrm{~b})$ to $\delta_{\mathrm{C}} 207.3(\mathrm{C}-4), 148.8(\mathrm{C}-3)$, and 50.1 (C-2), and the COSY cross peaks of $\delta_{\mathrm{H}} 2.81(\mathrm{H}-2)$ with $\delta_{\mathrm{H}} 6.10(\mathrm{H}-16 \mathrm{a})$ and $5.32(\mathrm{H}-16 \mathrm{~b})$. The oxygenated methylene at C6 was assigned on the basis of the key HMBC correlations from $\delta_{\mathrm{H}} 3.80(\mathrm{H}-6 \mathrm{a})$ and $3.39(\mathrm{H}-6 \mathrm{~b})$ to $\delta_{\mathrm{C}} 207.3$ $(\mathrm{C}-4), 54.5(\mathrm{C}-5)$, and $54.2(\mathrm{C}-1)$, and the COSY correlations of $\delta_{\mathrm{H}} 3.80(\mathrm{H}-6 \mathrm{a})$ and $3.39(\mathrm{H}-6 \mathrm{~b})$ with $\delta_{\mathrm{H}} 2.71$ $(\mathrm{H}-5)$. The HMBC correlations from $\delta_{\mathrm{H}} 3.32\left(\mathrm{H}_{3}-\mathrm{OMe}\right)$ to $\delta_{\mathrm{C}} 70.8(\mathrm{C}-6)$, and $\delta_{\mathrm{H}} 3.80(\mathrm{H}-6 \mathrm{a})$ and $3.39(\mathrm{H}-6 \mathrm{~b})$ to $\delta_{\mathrm{C}} 59.1(\mathrm{C}-\mathrm{OMe})$ indicated that the methoxyl was attached to C6. The planar structure of 2 was established by the analysis of HMBC and COSY spectra.

The relative stereochemistry of $\mathbf{2}$ was deduced from a NOESY experiment (Figure 3). The key NOESY correlations of $\delta_{\mathrm{H}} 1.05\left(\mathrm{H}_{3}-7\right)$ with $\delta_{\mathrm{H}} 2.81(\mathrm{H}-2)$ and $2.05(\mathrm{H}-11)$ suggested that $\mathrm{H}-2, \mathrm{H}_{3}-7$, and $\mathrm{H}-11$ are situated in the same side of the six membered ring and assigned as the $\alpha$-orientation. The proton of $\mathrm{H}-5$ was $\alpha$-oriented based on the key NOESY correlations of $\delta_{\mathrm{H}} 2.71(\mathrm{H}-5)$ with $\delta_{\mathrm{H}} 1.05\left(\mathrm{H}_{3}-7\right)$. The key NOESY correlations of $\delta_{\mathrm{H}} 1.11\left(\mathrm{H}_{3}-14\right)$ with $2.05(\mathrm{H}-11), 0.97\left(\mathrm{H}_{3}-15\right)$ with $1.35(\mathrm{H}-12 \mathrm{~b})$, and $\delta_{\mathrm{H}} 3.39(\mathrm{H}-6 \mathrm{~b})$ with $\delta_{\mathrm{H}} 1.35(\mathrm{H}-12 \mathrm{~b})$ assigned $\mathrm{H}_{2}-12, \mathrm{H}_{3}-14$, and $\mathrm{H}_{3}-15$ as $\beta$-, $\alpha$-, and $\beta$-orientation, respectively. Based on the above observations, the structure of 2 was determined to be $(3 S, 3 \mathrm{a} S, 4 S, 7 S, 7 \mathrm{a} S)$-3-(methoxymethyl)-4, 8 , 8-trimethyl-1-methylenehexahydro-3a, 7-ethanoinden-2(3H)-one (suberosain A).

Table 2. ${ }^{1} \mathrm{H}(500 \mathrm{MHz})$ and ${ }^{13} \mathrm{C}(125 \mathrm{MHz}) \mathrm{NMR}$ Spectroscopic Data in $\mathrm{CDCl}_{3}$ for $3\left(\delta_{\mathrm{H}}\right.$ and $\delta_{\mathrm{C}}$ in ppm,

\begin{tabular}{|c|c|c|c|c|c|c|c|}
\hline No & $\delta_{\mathrm{H}}$ & $\delta_{\mathrm{C}}$ & HMBC & No & $\delta_{\mathrm{H}}$ & $\delta_{\mathrm{C}}$ & НMBC \\
\hline 1 & $\begin{array}{c}2.09 \text { m, H-1a; } 1.42 \\
\text { m, H-1b }\end{array}$ & 37.2 & H-2a, H-9, H-19 & 12 & $1.48 \mathrm{~m}$ & 39.2 & H-17, H-18 \\
\hline 2 & $\begin{array}{c}2.44 \mathrm{td}(14.5,5.5 \\
\mathrm{H}-2 \mathrm{a}) ; 2.24 \mathrm{~m}, \mathrm{H}- \\
2 \mathrm{~b}\end{array}$ & 37.5 & $\mathrm{H}-1 \mathrm{a}, \mathrm{H}-1 \mathrm{~b}$ & 13 & & 44.3 & $\begin{array}{l}\text { H-18, H-17, } \\
\text { H-16, H-8 }\end{array}$ \\
\hline 3 & & 216.4 & $\begin{array}{l}\text { H-22a, H-2b, H- } \\
2 \mathrm{a}, \mathrm{H}-1 \mathrm{a}, \mathrm{H}-1 \mathrm{~b}\end{array}$ & 14 & $1.25 \mathrm{~m}$ & 56.6 & H-18 \\
\hline 4 & $2.76 \mathrm{~m}$ & 49.3 & H-2b, H-5 & 15 & $\begin{array}{l}1.72 \mathrm{~m}, \mathrm{H}-15 \mathrm{a} ; \\
1.70 \mathrm{~m}, \mathrm{H}-15 \mathrm{~b}\end{array}$ & 23.0 & $\begin{array}{l}\text { H-14, H-16, } \\
\text { H-17 }\end{array}$ \\
\hline 5 & $1.71 \mathrm{~m}$ & 46.0 & H-19, H-1a, & 16 & $1.68 \mathrm{~m}$ & 23.0 & $\mathrm{H}-14, \mathrm{H}-17$ \\
\hline 6 & $1.25 \mathrm{~m}$ & 24.4 & H-5 & 17 & $2.55 \mathrm{t}(8.75)$ & 63.8 & $\begin{array}{l}\text { H-12, H-16, } \\
\text { H-18, H-21 }\end{array}$ \\
\hline 7 & $\begin{array}{c}1.57 \mathrm{~m}, \mathrm{H}-7 \mathrm{a} ; 1.40 \\
\mathrm{~m}, \mathrm{H}-7 \mathrm{~b}\end{array}$ & 21.4 & & 18 & $0.64 \mathrm{~s}$ & 13.5 & H-12, H-17 \\
\hline 8 & $1.54 \mathrm{~m}$ & 35.6 & H-7a, H-7b, H-9 & 19 & $1.03 \mathrm{~s}$ & 23.1 & $\mathrm{H}-1 \mathrm{~b}, \mathrm{H}-9$ \\
\hline 9 & $1.58 \mathrm{~m}$ & 42.0 & $\begin{array}{c}\text { H-1a, H-1b, H- } \\
\text { 5, H-11a, H-12, } \\
\text { H-7b, H-19 }\end{array}$ & 20 & & 209.4 & H-17, H-21 \\
\hline 10 & & 35.6 & $\begin{array}{c}\text { H-1a, H-1b, H- } \\
2 \mathrm{a}, \mathrm{H}-2 \mathrm{~b}, \mathrm{H}-5, \\
\text { H-9, H-19 }\end{array}$ & 21 & $2.12 \mathrm{~s}$ & 31.5 & \\
\hline 11 & $\begin{array}{c}1.56 \mathrm{~m}, \mathrm{H}-11 \mathrm{a} ; 1.13 \\
\mathrm{~m}, \mathrm{H}-11 \mathrm{~b}\end{array}$ & 25.6 & H-9 & 22 & $\begin{array}{c}3.85 \mathrm{dd}(11.0,3.0 \\
\mathrm{H}-22 \mathrm{a}) ; 3.65 \mathrm{dd} \\
(11.5,5.5, \mathrm{H}-22 \mathrm{~b})\end{array}$ & 60.1 & \\
\hline
\end{tabular}


Compound 3 was obtained as a white powder. Its molecular formula, $\mathrm{C}_{22} \mathrm{H}_{34} \mathrm{O}_{3}$, was deduced from $\mathrm{HR}$ ESI-MS m/z $369.2393[\mathrm{M}+\mathrm{Na}]^{+}$(calcd. for $\mathrm{C}_{22} \mathrm{H}_{34} \mathrm{O}_{3} \mathrm{Na}, 369.2406$ ), suggesting that 3 had six degrees of unsaturation. Three methyls $\left(\delta_{\mathrm{H}} 0.64,1.03\right.$, and 2.12$)$ were observed in the ${ }^{1} \mathrm{H} N M R$ spectrum. The ${ }^{13} \mathrm{C}$ NMR, DEPT135, and HSQC spectra displayed the presences of three methyls $\left(\delta_{\mathrm{C}} 13.5,23.1\right.$, and 31.5), nine methylenes $\left(\delta_{\mathrm{C}} 37.2,37.5,24.4,21.4,25.6,39.2,23.0,23.0\right.$, and 60.1$)$, six methines $\left(\delta_{\mathrm{C}} 49.3,46.0,35.6\right.$, $42.0,56.6$, and 63.8), and four quaternary carbon atoms (including two carbonyl groups at $\delta_{\mathrm{C}} 209.4$ and 216.4). Comparison of their NMR spectroscopic data with those of $5 \beta$-pregnan-3, 20-dione indicated that they were highly similar except for an additional carbinol group in 3 [18]. The carbinol group was located at $\mathrm{C} 4$ based on the COSY correlations of $\delta_{\mathrm{H}} 3.85$ and $3.65\left(\mathrm{H}_{2}-4-\mathrm{CH}_{2} \mathrm{OH}\right)$ with $\delta_{\mathrm{H}} 2.76(\mathrm{H}-4)$. The position of other groups was assigned on the basis of analysis of HMBC correlations and ${ }^{1} \mathrm{H}-{ }^{1} \mathrm{H}$ COSY correlations (Figure 2). The key NOESY correlations of $\delta_{\mathrm{H}} 1.03\left(\mathrm{H}_{3}-19\right)$ with $\delta_{\mathrm{H}} 1.71(\mathrm{H}-5)$ indicated $\mathrm{H}-5$ was $\beta$-oriented. The key NOESY correlations of $\delta_{\mathrm{H}} 1.40(\mathrm{Hb}-7)$ with $\delta_{\mathrm{H}} 1.03\left(\mathrm{H}_{3}-19\right)$ and $2.76(\mathrm{H}-4)$ assigned $\mathrm{H}-4$ as $\alpha-$ orientation. Therefore, the structure of $\mathbf{3}$ was established as 4-hydroxymethyl-5 $\beta$-pregnan-3, 20-dione.

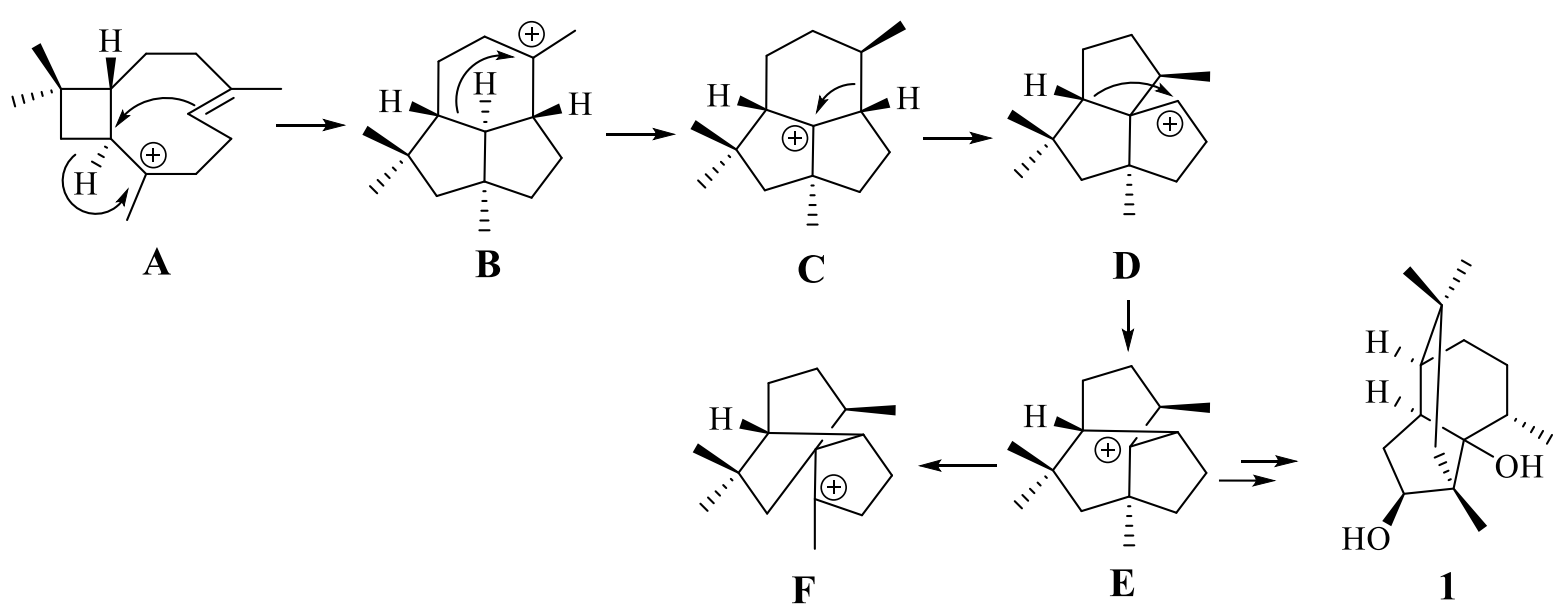

Scheme 1. The plausible biogenetic pathway of $\mathbf{1}$

In conclusion, two unique sesquiterpenes ( $\mathbf{1}$ and $\mathbf{2})$ and a new pregnane derivative $(\mathbf{3})$ were isolated from the South China Sea gorgonian S. suberosa. The previous investigations displayed the co-occurrence of several subergane, $\alpha$-caryophyllene with quadrone type sesquiterpenes in $S$. suberosa [3,5]. As shown in scheme 1, quadrone type sesquiterpenes are biogenetically derived from ring-expansion of the caryophyllenyl cation (A), following by $\pi$-cyclization and hydride shift to generate a key branchpoint cationic intermediate (C), and the following carbonium ion rearrangements generated quadrone type skeletal sesquiterpenes (F) $[19,20]$. The key intermediate $\mathrm{E}$ plays an important role in the biosynthesis of quadrone type skeletal sesquiterpenes; however, the intermediate E skeletal compounds have been undescribed. Isosuberosenol A (1) is the first intermediate E skeletal compound. Therefore, isosuberosenol A (1) provides some strong support for this plausible biogenetic pathway of quadrone type sesquiterpenes. The structure of $\mathbf{2}$ was similar to quadrone type sesquiterpene but had an exocyclic olefin at C3; therefore, the skeleton of $\mathbf{2}$ is different from that of quadrone type sesquiterpene. Compound $\mathbf{3}$ possessed the carbinol group at $\mathrm{C} 4$ which was extremely rare in the pregnane derivative.

\section{Acknowledgments}

This work was partially supported by the special fund for Bagui scholars to Yonghong Liu, the scientific research basic ablity improvement project of Guangxi universities yong and middle age teachers to XianQiang Chen (2019KY0309), the scientific research start-up fund for the introduced doctor of Guangxi univeristy of Chinese medicine to Xian-Qiang Chen (2018BS045), and special scientific research fund project for Institute of Marine drugs team of Guangxi univeristy of Chinese medicine to Yonghong Liu (2018ZD005-A01) and Xian-Qiang Chen (2018ZD005-A02). 


\section{Supporting Information}

Supporting information accompanies this paper on http://www.acgpubs.org/journal/records-of-naturalproducts

\section{ORCID}

Xian-Qiang Chen: 0000-0002-0545-1834

Nannan Xing: 0000-0003-1598-7621

Bin Yang: $\underline{0000-0003-4748-2484}$

Xuefeng Zhou: 0000-0001-9601-4869

Chenghai Gao: $0000-0003-4345-5470$

Yonghong Liu: $\underline{0000-0001-8327-3108}$

\section{References}

[1] G. Amiram, F. William, C.H. He, C. Jon, Z. Wu, Z. Yiao and K. Long (1985). Subergorgic acid, a novel tricyclopentanoid cardiotoxin from the pacific gorgonian coral, Tetrahedron Lett. 26, 2379-2382.

[2] S.H. Qi, S. Zhang, X. Li and Q.X. Li (2005). A cytotoxic sesquiterpene alkaloid from the South China Sea gorgonian Subergorgia suberosa, J. Nat. Prod. 68, 1288-1289.

[3] G.H. Wang, A.F. Ahmed, Y.H. Kuo and J.H. Sheu (2002). Two new subergane-based sesquiterpenes from a Taiwanese gorgonian coral Subergorgia suberosa, J. Nat. Prod. 65, 1033-1036.

[4] M.W. Xu and Y.T. Hao (2016). A new sesquiterpene from the South China Sea gorgonian coral Subergorgia suberosa, Nat. Prod. Res. 30, 2402-2406.

[5] G.H. Wang, A.F. Ahmed, J.H. Sheu, C.Y. Duh, Y.C. Shen and L.T. Wang (2002). Suberosols A-D, four new sesquiterpenes with $\beta$-caryophyllene skeletons from a Taiwanese gorgonian coral Subergorgia suberosa, J. Nat. Prod. 65, 887-891.

[6] P.S. Parameswaran, C.G. Naik, S.Y. Kamat, M.S. Puar, P. Das and V.R. Hegde (1998). Studies on the secondary metabolites from the Indian gorgonian Subergorgia suberosa: Isolation and characterization of four analogues of the cardiotoxin subergorgic acid, J. Nat. Prod. 61, 1074-1074.

[7] S. Qi, S. Zhang, L. Yang and P. Qian (2008). Antifouling and antibacterial compounds from the gorgonians Subergorgia suberosa and Scripearia gracillis, Nat. Prod. Res. 22, 154-166.

[8] W. Cheng, J. Ren, Q. Huang, H. Long, H. Jin, L. Zhang, H. Liu, L. van Ofwegen and W. Lin (2016). Pregnane steroids from a gorgonian coral Subergorgia suberosa with anti-flu virus effects, Steroids 108, 99-104.

[9] S. Qi, S. Zhang, Y. Wang and M. Li (2007). Complete ${ }^{1} \mathrm{H}$ and ${ }^{13} \mathrm{C} \mathrm{NMR}$ assignments of three new polyhydroxylated sterols from the South China Sea gorgonian Subergorgia suberosa, Magn. Reson. Chem. 45, 1088-1091.

[10] J. Zhang, L.L. Liu, B.L. Zhong, X.J. Liao and S.H. Xu (2015). 9,11-Secosteroids with cytotoxic activity from the South China Sea gorgonian coral Subergorgia suberosa, Steroids 98, 100-106.

[11] M. Liu, C.L. Shao, M. Chen, J. Qi, Y. Wang, Y.C. Fang and C.Y. Wang (2014). Bioactive 9,11-secosteroids from gorgonian Subergorgia suberosa collected from the South China sea, Chem. Biodivers. 11, 1109-1120.

[12] S.H. Qi, S. Zhang and H. Huang (2008). Purine alkaloids from the South China Sea gorgonian Subergorgia suberosa, J. Nat. Prod. 71, 716-718.

[13] H. Bokesch, T. McKee and J. Cardellina (1996). Suberosenone, a new cytotoxin from Subergorgia suberosa, Tetrahedron Lett. 37, 3259-3262.

[14] J. Sheu, K. Hung, G. Wang and C. Duh (2000). New cytotoxic sesquiterpenes from the gorgonian Isis hippuris, J. Nat. Prod. 63, 1603-1607.

[15] C. Subrahmanyam, S.R. Kumar and G.D. Reddy (2005). Bioactive compounds from the Indian Ocean gorgonian Subergorgia suberosa (Pallas), Indian J. Chem. 44B, 2186-2188.

[16] J. Zhang, W. Ling, Z. Yang, Y. Liang, L. Zhang, C. Guo, K. Wang, B. Zhong, S. Xu and Y. Xu (2019). Isolation and structure-activity relationship of subergorgic acid and synthesis of its derivatives as antifouling agent, Mar. Drugs 17.

[17] J. Zhang, Y. Liang, K.L. Wang, X.J. Liao, Z. Deng and S.H. Xu (2014). Antifouling steroids from the South China Sea gorgonian coral Subergorgia suberosa, Steroids 79, 1-6.

[18] C.J. MacNevin, F. Atif, I. Sayeed, D.G. Stein and D.C. Liotta (2009). Development and screening of watersoluble analogues of progesterone and allopregnanolone in models of brain injury, J. Med. Chem. 52, 6012-6023. 
[19] R.M. Coates, J.Z. Ho, M. Klobus and L. Zhu (1998). Carbocationic rearrangements of silphinane derivatives, J. Org. Chem. 63, 9166-9176.

[20] M. Presset, Y. Coquerel and J. Rodriguez (2010). Quadrane sesquiterpenes: Natural sources, biology, and syntheses, Eur. J. Org. Chem. 2247-2260.

\section{A C G \\ publications \\ (c) 2019 ACG Publications}

